\title{
REVIEW ARTICLE: THE USE OF RABBINIC SOURCES IN GOSPEL STUDIES
}

\author{
David Instone Brewer
}

\begin{abstract}
Summary
New Testament scholars tend to avoid rabbinic sources because of the problem of dating. This is a genuine problem, but it is not insurmountable. The work of Neusner and others has highlighted this problem but it has also indicated some ways to deal with it. This review article looks at three recent books which demonstrate the usefulness of rabbinic background for studying the Gospels. All three have dealt with the problem of dating, with varying success. Brad Young has produced a useful book on the Parables, though he tends to compare them with the theology of post-Temple Judaism. Roger Aus' studies sometimes suffer from parallelomania, though his investigation of the woman caught in adultery is masterful. Maurice Casey's search for the Aramaic behind Mark leads him into creative and sometimes compelling arguments based on rabbinic texts. All three clearly believe that they can identify early rabbinic material and deal with it critically, and on the whole they appear to have succeeded. They have employed traditional scholarship, historical criticism and literary criticism. New Testament scholarship would greatly benefit from the additional use of redaction criticism of rabbinic material, as developed by Neusner and others.
\end{abstract}

\section{The problem of dating}

The key to using rabbinic sources is dating. This principle became the consensus after the publication of the influential first volume of the Brown Judaic Studies. ${ }^{1}$ There are now more than 300 titles in this series, about half of which are by Jacob Neusner. The first volume was a collection of papers on methodology and of examples of how to use rabbinic material for New Testament studies. The short

I Green, William Scott, ed., Approaches to Ancient Judaism: Theory and Practice, Brown Judaic Studies 1 (Missoula, Mont.: Scholars Press for Brown University, 1978). 
concluding paper by Neusner warned about the dangers of dating. The warning was obvious even in the title of his paper: 'The Use of the Later Rabbinic Evidence for the Study of First-Century Pharisaism'? ${ }^{2}$

This warning has been taken so seriously that New Testament scholarship has tended to steer clear of Jewish sources. David Aus has complained:

Many NT scholars today employ the genuine problem of dating rabbinic
sources... as a cheap pretext for not even considering them...I would be
the first to concede that much of what is Amoraic and even some of what
is ostensibly Tannaitic is late and of doubtful relevance to NT narratives.
Yet a number of Jewish traditions from before 70 CE have been retained
in the (patently later) rabbinic writings. Each individual tradition must be
analyzed and evaluated on its own merits, which I try to do. ${ }^{3}$

The problem is that very few scholars feel that they are competent to analyse and evaluate the dating of every Jewish source they wish to use, so they avoid these sources.

The use of later materials for Jewish background is not just a matter of scholarly indiscipline. The world of rabbinic Judaism after the destruction of the Second Temple in $70 \mathrm{CE}$ is very different from that of Rabbinic Judaism before this momentous event. The observant reader will notice that the preceding sentence used 'rabbinic' for pre-70 CE Judaism and 'Rabbinic' for post-70 CE Judaism. This is because the ordination of Rabbis and the use of 'Rabbi' as a title started when Judaism was ruled from the Academies of Yavneh and Usha. This change represented a dramatic rise in their status after the destruction of the Temple and the demise of their rivals, the Sadducees and the Essenes. They also became less diverse, with the virtual disappearance of the Shammaites and other smaller factions. Their theology contained less emphasis on ceremonies (most of which were impossible after the destruction of the Temple) and an increasing emphasis on study and prayer.

As a consequence of their new-found status as ruling legislators their interests moved from everyday matters of rural life into tort and legal compensation. Neusner has demonstrated the different concerns of the rabbinic authorities in different periods. He has analysed the internal development of Mishnaic tractates and divided their progress into five periods: pre-1st century, 1-70 CE, 70-120 CE

2 Green, Approaches, 215-25.

3 Aus, Roger David, 'Caught in the Act', Walking on the Sea, and the Release of Barabbas Revisited. South Florida studies in the history of Judaism; 157 (Atlanta: Scholars, 1997), x. 
(the Yavnean period), 140-170 CE (the Ushan period) and post $170 \mathrm{CE}$ (the time of Rabbi, Judah ha-Nasi). He found that their concerns changed with time. In the early periods there was much more emphasis on cleanliness ${ }^{4}$ and in the later periods there was much more emphasis on litigation and oaths. ${ }^{5}$ This reflects the rise of the rabbis from the status of local experts on the law for the common people before $70 \mathrm{CE}$ to their role of legal administrators for the whole of Judaism after $70 \mathrm{CE}$.

My own work on rabbinic Scripture exegesis ${ }^{6}$ has shown that this is another area where significant changes took place after $70 \mathrm{CE}$. With their newly acquired authority came the need to frame legislation. A completely novel methodology of exegesis was developed by which new laws could be derived from obscure hints within Scripture. The exegetical methods of the early Palestinian rabbis and even their underlying assumptions about the nature of Scripture show dramatic development. Before $70 \mathrm{CE}$ rabbinic exegesis did not use allegory, propose textual emendations, remove a text from its context, or look for multiple levels of meaning in a text, although all these methods were common after $70 \mathrm{CE}$. Some of these methods were already used at Qumran and Alexandria, but they did not enter rabbinic Judaism till after the destruction of the Temple. This has profound importance for the study of the New Testament, especially with regard to its use of the Old Testament.

Therefore, although it is correct to identify the Rabbis as the successors of the pre-70 CE rabbinic traditions, there are too many

4 In his conclusion to a 22 volume study of the Order of Purities, Neusner says that he still has not discovered why Judaism completely lost interest in almost all the matters dealt with in that Order. Before $70 \mathrm{CE}$, a conscientious Jew would go through purification rituals after touching a dead body, but it was completely different after the completion of the Mishnah. 'There is no evidence that rabbis or ordinary folk took an interest in eating their ordinary food as if they were priests in the Temple, and so, for example, refrained from eating lunch if, en route to the table, they stepped on a dead snake.' (Neusner, Jacob, A History of the Mishnaic Law of Purities, Studies in Judaism in late antiquity, 22 vols., Leiden: Brill, 1974-1997, vol. 22, xiv).

5 At the end of his five volumes on Damages, Neusner concludes that the whole subject of Oaths should be dated after $70 \mathrm{CE}$, and the whole system of Damages did not get underway till after 160 CE (Neusner, Jacob, A History of the Mishnaic Law of Damages, Studies in Judaism in late antiquity, 5 vols., Leiden: Brill, 1983-1985, vol. 5, 151f.).

6 Instone Brewer, David, Techniques and Assumptions in Jewish Exegesis before $70 C E$, Texte und Studien zum antiken Judentum; 30 (Tübingen: Mohr, 1992). Originally presented as a Ph.D. thesis at Cambridge University. 
differences to allow us safely to use later material for illustrating earlier periods.

On the positive side, these studies have confirmed that it is possible to date rabbinic material. The very fact that differences have been discovered suggests that different bodies of literature have been successfully isolated from each other. The dating in both my work and Neusner's was based largely on attributed sayings, though I also included early groups of material such as Pharisee-Sadducee disputes. ${ }^{7}$ Of course the attribution of a saying to a particular rabbi cannot be taken at face value, but it forms a very good starting point. ${ }^{8}$ As well as this, one has to look at form and context, and the motivation for citing the authority. In general, the attributions have proved to be a very reliable guide, though one must bear in mind that no sayings have been preserved without later editing. Therefore a saying should be regarded as preserving the opinions of early rabbis, but almost never their actual words.

This review article will look at three recent examples of Gospel studies that have relied on rabbinic sources. All three authors are aware of the importance of dating, and all are competent to date rabbinic material. They have all been careful to use early sources and to discuss the problems of dating, and yet even they have fallen into the trap of using late material occasionally. In some cases this has completely invalidated their argument. These three can also be seen as examples of different approaches to rabbinic studies, employing traditional scholarship, historical criticism and literary criticism. I have employed these labels loosely, in the realisation that each author has employed all of these techniques to some degree. These categories are nevertheless useful as an overview of what is happening in the use of rabbinic sources in New Testament studies.

7 The dating I used in my work has never been criticised in the dozens of reviews it has received. Many of these reviewers have questioned my findings, perhaps because they overturned most of what was written in this area previously, but they did not seek to undermine them by questioning my dating techniques.

8 Neusner, who would be the first to warn about over-reliance on dating by attribution, says: 'The temporal order of attributions is generally sound...In every instance [in the tractate Kelim], except that just cited [mKel. 17.5], in which we are able to establish the expectation that the substance of a given law is prior to that of another closely related rule, the earlier rule also will be assigned to an earlier authority, the later rule to a later authority.' (Purities vol. $3,239)$. 


\section{Traditional scholarship}

A division has grown between the scholars who regard themselves as the successors of traditional Jewish learning and the newer scholars who regard traditional scholarship as 'precritical'. The sometimes extreme antipathy of these two groups towards each other is well illustrated in Neusner's account of his interactions with the Israel Historical Society.

In challenging the premises of a hundred years of 'Talmudic history', which treated as facts whatever the sources alleged, so that if a saying was attributed to a sage, he really made that saying in the time in which he lived, and if a story was told, the event really happened in that way, in that language, I rendered obsolete and historically worthless several generations of work, not to mention that of my own contemporaries and their students. When in 1984, submitting my paper in advance, I told the Israel Historical Society that everything they had printed in their journal Zion in this area was null, I got myself disinvited from the conference at which I was to give the keynote address. No wonder, then, that for the first twenty years of my career I could not publish a book in the USA, and until Ephraim E. Urbach died, my books were kept along with pornography under lock and key in the library of the Hebrew University. ${ }^{9}$

A few scholars manage to bridge this divide, using the disciplines of critical analysis without abandoning the treasures of traditional rabbinic scholarship. The older rabbinic scholars not only knew the sources by rote, but understood them, and understood the way the original editors thought, because they belonged to the same ongoing tradition. The downside to this is that they tended to read ancient sources through the understanding of later development, so they were sometimes blind to the differences between ancient tradition and its later development.

One of the scholars who has managed to learn from both fields of scholarship is Brad Young.

Young, Brad H., The Parables: Jewish Tradition and Christian Interpretation (Peabody: Hendrickson, 1998), xv +332 pp.; $24 \mathrm{~cm}$.

Brad Young's book is a helpful summary of previous work on the parables together with helpful new insights from rabbinic sources. Young is a student of David Flusser, which is very evident throughout this book. He has been greatly influenced by Flusser and

9 Foreword to Gerhardsson, Birger, Memory and Manuscript, Acta Seminarii Neotestamentici Upsaliensis 22 (Uppsala, 1961), Republished by Eerdmans, 1998 with Tradition and Transmission in Early Christianity, xxix. 
by other Israeli scholars such as Safrai who have attempted to put the early rabbinic material into a historical context, while preserving as much as possible of the valuable insights from traditional rabbinic scholarship. Their ambitious ongoing project, the Compendia Rerum Iudaicarum ad Novum Testamentum, is an attempt to describe the historical and social world of Judaism in the first two centuries. This has largely succeeded in placing early rabbinic material within a coherent picture constructed from other sources. Young appears to be attempting a similar project here for the Parables. He wants to show that the parables of Jesus stand within the tradition of rabbinic parables, and that Jesus' theology is virtually identical with that of the early rabbis.

Most of his work is a compilation of previous work, especially that of Jeremias, who referred to all the useful rabbinic material, ${ }^{10}$ and that of Kenneth Bailey, who brought new insights from the social world of Arabic villages. ${ }^{11}$ David Flusser is also cited regularly, mainly with regard to his assertion that early rabbinic theology has been misunderstood by Christians, and that it was actually based on God's love and not on legalism. ${ }^{12}$ The fact that Young has succeeded in bringing new light into this well-worked area of New Testament studies is a real achievement. Most of his new light is, however, the idea that Jesus' theology is virtually identical to that of the Pharisees which, in my opinion, he fails to demonstrate convincingly.

A good example is the parable of the Prodigal or the parable of the Two Lost Sons as Young usefully renames it. He highlights the oral law which Jeremias showed was lying behind this parable, that a father was allowed to distribute his estate before his death, and still retain a certain level of control over it. ${ }^{13}$ To this he adds Bailey's insight from village life, that the elder son is just as self-seeking as the younger, because he should have tried to dissuade his father

10 Jeremias, J., The Parables of Jesus, Trans. by S.H. Hooke, (2nd rev. ed. New York: Scribner's, 1972).

11 Bailey, Kenneth E., Finding the Lost (St. Louis: Concordia, 1992), Poet and Peasant (Grand Rapids: Eerdmans, 1976) and Through Peasant Eyes (Grand Rapids: Eerdmans, 1980).

12 Especially in Judaism and the Origins of Christianity (Jerusalem: Magnes, 1989).

$13 m B B$. 8.7. Young does not discuss the dating of this ruling, except to say that the parable makes no sense without it. An early date for this ruling can probably be justified on the basis of $m$ Ket. 9.8 where a widow claims her inheritance from orphans, presumably on the basis of an agreement made before her husband's death. 
from making this arrangement. Young's own contribution is to reveal the theological implications of this. Both sons regarded their father as someone to be obeyed, not loved. The returning son says 'treat me as one of your hired servants' (Lk. 15:19) while the son who remained says 'these many years I have served you and never disobeyed your command' (Lk. 15:29). The parable was to teach both the faithful and the repentant sinner that God wants to be their Father not their Master.

So far, very good, but then Young attempts to show that early Pharisaic Judaism already had this same theology. The only text he can produce to back this up is the saying of Antigonus of Socho (2nd century BCE):

Be not like slaves that serve the master for the sake of receiving a reward, but be like slaves that serve the master not for the sake of receiving a reward, and let the fear of Heaven be upon you. $(m A b .1 .3)$

This passage has been the source of a great deal of discussion and development. In later rabbinic interpretation it is certainly true that this saying was thought to teach the concept of serving God for the sake of love alone. In the absence of further texts, Young cites Flusser: 'Yet we have to bear in mind that this logion is but one expression of a new, profound sensitivity that developed within Judaism, which later on was so much taken for granted that it became a second nature, a sensitivity that, in turn, Christianity took over from contemporary Judaism.' 14

When one reads the saying of Antigonus in the light of later Judaism, it is easy to read into it the concept of serving God for the sake of love. But the saying by itself suggests the concept of a stick rather than a carrot. Antigonus appears to be saying that we should not serve for the sake of a reward, but for fear of the consequences if we do not serve well.

In contrast, Jesus did stress rewards, ${ }^{15}$ though one's reward was usually a commendation or a declaration of love from the Father. The parables of talents/pounds appears at first glance to allocate money or responsibility as a reward, but the real reward is the commendation 'Well done' (Mt. 25:21; Lk. 19:17). Even the mercenary unjust

14 Flusser, Origins, 472f.

15 As Young confusingly affirms on p. 277 where he says that the early Pharisees did teach rewards: 'Like the Pharisees, Jesus emphasized reward and punishment.' I agree that the early Pharisees taught rewards (cf. Ben Hé Hé at $m A b$. 5.23: 'According to the effort is the reward') but this does not mean that they emphasised God's love. 
steward is rewarded with a commendation and with friends in heaven rather than wealth (Lk. 16:8f.). Jesus also stresses God's love, for repentant sinners as well as for the righteous. Flusser, in his foreword to Young's book, makes the point that although the rabbis portrayed God as accepting the sinner, they did not include Jesus' emphasis on 'divine favor given to the outcast'. ${ }^{16}$ Perhaps he noted this in order to compensate for Young's over-enthusiasm to demonstrate Jesus' similarity to contemporary Jews.

There is certainly a great deal of similarity between the theology of Jesus and the theology of the Rabbis after $70 \mathrm{CE}$. Young highlights much of this, though he consistently suggests that these texts represent earlier thought. 17 Yohanan ben Zakkai, who is reputed as the founder of post- $70 \mathrm{CE}$ Judaism, often sounds like a disciple of Jesus. Young points to his parable of the wise and foolish servants who arrived at a banquet dressed suitably and unsuitably respectively. The foolish servants were left outside like the foolish virgins and the unsuitably dressed wedding guests of Jesus' parables. ${ }^{18} \mathrm{He}$ also compares Yohanan's saying that a good heart encompasses all other virtues with the parable of the Sower where the seed grows in a good heart. ${ }^{19} \mathrm{He}$ does not refer to the most striking parallel, where Yohanan tells his disciples that God desires mercy, not sacrifice, using exactly the same terminology and scripture reference as Jesus. ${ }^{20}$ This was the lesson which Yohanan had to teach to Judaism after the destruction of the Temple, but which Jesus had already taught to his disciples.

Young has succeeded in demonstrating many similarities between the theology of Jesus and the theology of the Rabbis after $70 \mathrm{CE}$ but he has failed to demonstrate that the rabbis before $70 \mathrm{CE}$ followed

\footnotetext{
16 Flusser's Foreword p. $\mathrm{x}$.

17 E.g. Young, Parables, 166, 'One rabbi in particular, R. Abbahu, may represent a line of earlier interpreters within the chain of teachers in Pharisaicrabbinic Judaism when he links those who are far with the ones who repent from sin and those who are near with the completely righteous.' But R. Abbahu is a third generation Palestinian Amora, who died after $300 \mathrm{CE}$.

18 RuthR. 3:3, cf. Mt. 22:11; 25:1-12. See Young, Parables, $281 \mathrm{f}$.

$19 m A b .2 .13$, cf. Lk. 8:15.

${ }^{20} A R N a$ 4, cf. Mt. 9:13; 12:7. See the discussion in J. Neusner's early work, $A$ Life of Rabban Yohanan Ben Zakkai, c. 1-80 C.E. Studia Post-Biblica 6 (Leiden: Brill, 1962), 142-44, where he suggests that Yohanan and Jesus use the same interpretation of hesed. This tradition is likely to be later than Yohanan. Although $A R N$ contains very early material, and this looks like a baraita within $A R N$, the fact that it does not occur elsewhere suggests that it was added by later editors. Its pivotal position at the beginning of a discussion may, however, suggest that it was an early source which helped to initiate the later discussion.
} 
this same theology. This is like someone who demonstrates that the theology of Luther is very similar to the theology of the Counter Reformation. The Counter Reformation occurred about a generation after Luther, when the Catholic Church discovered for itself many of the doctrines for which they had excommunicated Luther. At the end of Young's book one is left wondering why the Pharisees did not embrace Jesus. The problem is that Young has inadvertently compared Jesus with the successors of the Pharisees, because he has given insufficient attention to the dating of his sources.

\section{Historical criticism}

One of the earliest discoveries of Neusner was that biographical material about the rabbis has very little historical value. This was such a serious problem that he was forced virtually to repudiate his earlier works Development of a Legend (on the life of Yohanan ben Zakkai) and his five volume History of Jews in Babylonia. This conclusion does not mean that rabbinic sources do not contain any historical details, but it does mean that one should be particularly careful about biographical details, which were largely added by later generations. Historical details in rabbinic sources have, in many cases, been confirmed by referring to external sources. The most reliable details are the incidental ones, and the ones which occur in the earliest Tannaitic compilations (Siphra, Siphré, Mekhilta, Mishnah, Tosephta). But even these need confirmation by other primary sources before they can be accepted at face value.

All three of the authors examined here use historical criticism well, though some outstanding examples are found in the work by Aus.

Aus, Roger David, 'Caught in the Act', Walking on the Sea, and the Release of Barabbas Revisited. South Florida studies in the history of Judaism; 157 (Atlanta: Scholars, 1997), xi + 184 pp.; 24cm.

Roger Aus has published three separate essays on the rabbinic background to the Gospels, as listed in the title: 'Caught in the Act', Walking on the Sea, and the Release of Barabbas. The second and third essays are examples of what Sandmel called 'parallelomania'.21 They try to show that the story of walking on the sea was a retelling of a targumic account of Moses parting the Red Sea and that the

21 Sandmel, S., 'Parallelomania', JBL 81 (1962), 1-13. 
release of Barabbas was inspired by Josephus' account of the release of a prisoner by Archelaus. The verbal parallels with the Sea accounts may be significant, because Matthew in particular wished to highlight relationships between Moses and Jesus. But the idea that early Christians invented the Barabbas incident based on Josephus' account of Archelaus' supposed prisoner release, ${ }^{22}$ and then expected it to be received as historical, is too far-fetched. The first essay is no less ingenious, but here Aus uses his impressive knowledge of first century sources to much better effect.

Aus sets out to do two seemingly impossible things with the story of the adulterous woman who was 'caught in the act' (Jn. 7:538:11). First he attempts to show that this is a historically valid account of an incident in the life of Jesus, while most scholars regard it as an apocryphal addition to a late Gospel. Then he attempts to discover the actual words which Jesus wrote in the sand: He concludes that Jesus wrote the first words of a couple of scripture texts, and he even suggests the precise texts which help to explain the details of the account. His conclusions about the writing in the sand are probably too clever to be true, though his arguments are so enticing that $I$ find it difficult to make an unbiased judgement about them. His arguments for the historical veracity of the account are similarly convincing, though perhaps not enough to overcome the real problems with the history of transmission of the text itself. They are, however, a model of how to use rabbinic sources with historical integrity.

The historical problem with the account lies mainly in the fact that Jews did not have the power of capital punishment at this time, and rabbinic authorities did not appear to be in favour of capital punishment in any case. Most commentators assume that this incident, if it happened, was an example of mob lynching. But this lynch mob supposedly met in a very public place, probably within sight of the Roman soldiers stationed in the Tower of Antonia, overlooking the Temple court. This mob, which was led, strangely, by rabbinic and scribal authorities, went as a delegation to Jesus, and then supposedly waited patiently for his decision.

22 Wars $2: 1-13$; Ant. 17:200-218. This account does not actually mention the prisoner release. The fact that Judas was released at this time has to be inferred from the facts that Caesar later criticised him for releasing Herod's prisoners (Wars 2:28), that Herod imprisoned Judas and Matthias (Wars 1:654-55) and that Matthias is executed in Ant.17:160-67 without any mention of what happened to Judas. See Aus, Caught, 141-49. 
Aus highlights the ruling in Mishnah Sanhedrin 9.6 which lists five criminal acts which are liable to immediate punishment. One of them is a Jewish man 'who has sexual intercourse with an Aramaean woman-zealots strike him down'. Danby translates this as 'fall upon him' and Neusner has 'beat him up' but Albeck notes that 'those permitted to do so kill him at the site of the deed'. This probably refers to the Munich MS which adds in another hand the explanatory phrase 'at the moment of the dead', which is probably equivalent to John's phrase 'in the very act'. ${ }^{23}$ He shows that this Mishnaic ruling fits into the historical realities of the first century when it is likely that it was accepted literally. His arguments are based mainly on the work of Hengel, ${ }^{24}$ and on the traditions in mSanh. 7.2 where a daughter of a priest was burnt to death for adultery in Jerusalem (i.e. before $66 \mathrm{CE}$ ) and bSanh. 52b where R. Eleazar b. Zadok remembers seeing such an execution as a child. This ruling presupposes that sexual relations with all Gentiles were prohibited, and not just those listed in Deuteronomy 7:1-3, and Aus shows that the commandment had already been widened in this way by the time of the Houses and probably long before. ${ }^{25}$ Aus also deals with other problems such as the absence of the man with whom she was caught, whom Aus argues was a Roman who was not subject to this law.

The historical background which Aus adduces (which is covered very scantily here) is impressive and convincing, though he does not address the very real problems of textual criticism, except to say that the early church would have had good reasons to suppress the passage on moral grounds. Whether or not one concludes that he has succeeded in rehabilitating this uncertain incident, he has used rabbinic sources to very good effect. Rabbinic material often has far greater problems of textual criticism than Gospel texts, and yet, when brought together in this way, the two sets of uncertainty help to cancel each other out by demonstrating a coherent picture of pre70 CE Jewish society.

23 Aus adds that Kuhn in his German translation of Sifre on Numbers, at Nu. 25 sees it as an apt illustration of mSanh. 9.6, which he quotes with the phrase 'at the moment of the deed', and thus Kuhn seems to believe it was part of the original text.

24 Hengel, Martin, The Zealots: Investigations into the Jewish Freedom Movement in the Period from Herod I until 70 A.D. translated by David Smith, (Edinburgh: T. \& T. Clark, 1989).

25 This is based on the House material in $b A Z .36 \mathrm{~b}$ and the fact that Ezra had already widened it in Ezra 9-10. 


\section{Literary criticism}

Textual criticism is very poorly developed in rabbinic literature, and form criticism has failed to produce many useful results. Nevertheless literary criticism of a very simple kind, based on the attribution of sources to named rabbis, has proved far more useful than might have been imagined.

Textual criticism cannot really progress till full critical texts are available. Although some critical texts have already been prepared for most rabbinic works, the scope of these is often limited. New critical editions which take into account the Geniza fragments and a wider range of manuscripts are being prepared and some parallel text editions are being printed, so a great deal of useful work in this area may be expected in the future.

Form criticism has been explored in great detail in Neusner's Rabbinic Traditions, but the findings are disappointing. The transmission of rabbinic material tends to impose its own form on traditions. Traditions have been edited both for ease of memorisation and also for conformity with other traditions which deal with the same subject. In general, the opinions have been transmitted accurately, but not the form and sometimes not even the vocabulary of the original. One useful conclusion from Neusner's work is that the House collections (the debates between the schools of Hillel and Shammai) were edited in a relatively final form soon after $70 \mathrm{CE}$ and although later editors have added glosses and commentaries, the original content has been essentially preserved. ${ }^{26}$

Another useful conclusion is that attributions of sayings to particular rabbis is generally accurate. When inaccuracies do occur, they tend to involve attributing a rabbi with the words of a contemporary from the same academy. This means that attributions can be used as an easy and relatively trustworthy guide to dating. But this should not be done simplistically. One should always bear in mind that opinions may be attributed to famous early individuals in order to give them added weight, and also that even rabbinic memories are fallible.

All three of our authors use attributions to date sources, and Casey has some good examples of intelligent use of this method. Casey is also one of the few scholars to tackle the question of languages in rabbinic sources.

26 Neusner, Traditions, vol. 2, pp. 3-4. 
Casey, Maurice, Aramaic Sources of Mark's Gospel, Society for New Testament studies monograph series; 102 (Cambridge: CUP, 1998), $\mathrm{x}$ +278 pp.; $23 \mathrm{~cm}$.

Maurice Casey uses rabbinic literature mainly as a source of early Aramaic in his quest for the Aramaic background to the Gospel of Mark. Previous scholars who have set off down this path ${ }^{27}$ have been constrained by the lack of first century Aramaic texts, and Casey recognises that they laid too much weight on the few examples of early Aramaic in rabbinic literature. The discoveries at Elephantine, Qumran, and other caves of the Judaean desert have expanded our knowledge of early Aramaic to a huge extent. Casey attempts to use this knowledge to reconstruct a few texts of Mark's Aramaic. Like Aus, Casey sometimes spoils his carefully constructed arguments with some less well founded conclusions. ${ }^{28}$ On the whole, however, his arguments are well reasoned and often compelling.

He has very clear ideas about the reason why rabbinic sources use a mixture of Hebrew and Aramaic. The Mishnah is in Hebrew with a few traditions in Aramaic, while the Talmuds are in Aramaic with quotations from Mishnah and a few other traditions in Hebrew. Casey gives a simple reason for this: Aramaic was the language of the common Jew and Hebrew was the language of the scholar before $70 \mathrm{CE}$, though Aramaic took over in scholarly circles after $70 \mathrm{CE}$. He backs this up with evidence from Qumran and a growing body of early Aramaic literature. ${ }^{29}$ This means that, generally speaking, Aramaic sources in Mishnah are early traditions from outside the scholarly world, and Hebrew sources in the Talmuds are early scholarly sources from before $70 \mathrm{CE}$. Taken simply, these are very unsafe conclusions. Neusner has pointed out that Hebrew is also used when the Talmud wishes to make an authoritative statement. 30

27 Principally J.T. Marshall, A. Meyer, G.H. Dalman, C.C. Torrey and M. Black. Casey gives a detailed overview of their work (pp. 6-32) where he shows that most of their 'discoveries' have had to be abandoned in the light of the new knowledge about first century Aramaic and about translation techniques.

28 E.g., he convincingly suggested that Jesus' reference to Mal. 3:1 in Mk. 9:12 might lead Jesus to Is. 40:3 and the theme of suffering in Is. 40:6-8, but then he says, with equal certainty but with insufficient evidence, that this would lead him to Job 14 and to Jer. 6:27ff. and on to Jer. 7. (pp. 126-28).

29 Pp. 73-81.

30 Neusner, Jacob, How to Study the Bavli: The Languages, Literatures, and Lessons of the Talmud of Babylonia, South Florida studies in the history of Judaism; 37 (Atlanta: Scholars, 1992), 15-30. 
However, in conjunction with other indications, the language used is a valuable clue for dating sources.

Casey uses rabbinic material partly as a source of literary background in which to discover first century Aramaic usage and partly as a source of historical background against which to test his conclusions. Dating is extremely important for both these purposes. Casey dates sources by the commonly accepted methods of attribution and comparisons with contemporary history, but he also keeps an eye on the style of language used. When he uses attributions of sayings for dating, he does not do this in a simplistic manner, though he generally assumes that attributions are accurate. $\mathrm{He}$ is also willing to date anonymous sources by comparison with early literary evidence or historical circumstances. He is always careful to consider matters of dating, even when this appears to run counter to his main argument. For example, when he investigates the corn-plucking on the Sabbath, he concludes that there was no halakhah prohibiting this at the time of Jesus. Plucking (תלשי) does not occur in the list of 22 types of prohibited work in Jubilees 2:23, or in the list of 39 types in Mishnah (mShab. 7.2, cf. bShab. 73b). It occurs in the Tosephta (tShab. 9.17) though only with regard to endive, not grain, and it is implied in Philo (Life of Moses 2.22), but it is only specifically ruled against in the third century (yShab. 7.2). Casey is able to show that the Qumran sectarians had a stricter halakhah which would have included plucking (CD 10.22f.) and suggests that many early rabbis would also have ruled it out. ${ }^{31}$ Casey could have referred to Tosephta, backing this up with evidence from Philo and Qumran, and he could have referred to the passage from Mishnah as a parallel without mentioning the absence of 'plucking' in that text. It is impressive that Casey has successfully argued for the historicity of this dispute without cutting corners in the way many scholars might be tempted to do.

An example of using contemporary history to date an anonymous source is found in his discussion of the man healed on the Sabbath (Mk. 3:1-6). Jesus appears to appeal to the rabbinic principle that saving life overrides the Sabbath regulations. The earliest record of this principle is in a mid-2nd century debate. ${ }^{32}$ Casey argues that it originates in the time of the Maccabees. He refers to the story of the Sabbath day attack on the Jews in 1 Maccabees 2:29-38, after which

31 This is a summary of Casey's argument on pp. 146-48.

32 Mekh.Shab 1, Ex. 31.12-17-a debate between Aqiba and Jose the Galilean. 
Mattathias decided that defence of life was allowed on a Sabbath (vv. 39f.). He finds the origin of the rabbinic principle in this event.

On one occasion he argues that a ruling is slightly earlier than the attribution might suggest. While looking at the chronology of the Passion narrative, he considers the possibility that Passover sacrifices may have been brought on the 13th as well as the 14th of Nisan (the date of Passover). He points to the debate between R. Joshua and Ben Bathyra in $m Z e b .1 .3$ where they mention those who brought sacrifices on the 13th. These are both early Yavnean Rabbis who taught after $70 \mathrm{CE}$ but Casey argues that their debate took place before the Temple was destroyed. Casey argues that they were unlikely to invent the idea that Temple practice did not strictly follow Scripture (which says that Passover sacrifices must be brought only on the afternoon of the 14th). While this is true, it is still unlikely that their debate can be dated before $70 \mathrm{CE}$. Although they lived at this earlier time, their teaching occurs after $70 \mathrm{CE}$, and their debate in the Mishnah is part of a series of debates by other Yavnean rabbis. It is therefore much more likely that their debate is part of the common tradition of debating Temple practices which took place after the Temple was destroyed.

However, it is possible to find pre-70 CE material in this debate, though one has to look behind the debate which Casey referred to. Joshua and Ben Bathyra were debating an obscure anonymous ruling in $m Z e b .1 .1$ which, as Casey himself points out, only makes sense in the light of $m Z e b .1 .3$. This earlier anonymous ruling refers to those who brought Passover sacrifices at times other than the afternoon of the 14th. Joshua and Ben Bathyra debate the reason why anyone would bring a Passover sacrifice at the wrong time. They both assume that people brought Passover sacrifices on the 13th, but they differ about the reason why they did this. Now, the fact that they were debating and explaining this anonymous ruling in $m Z e b .1 .1$ suggests that it dated from a time earlier than themselves, so it must have come from the Temple period. It is also likely that they correctly recalled the practices in the Temple times, which occurred just a few years previously and within their adult lifetime. Therefore Casey was correct to conclude that this practice dated back to Temple times, though he was a little loose with his argument from attribution. 


\section{Redaction criticism}

None of our authors has used redaction criticism to help them date early sources for Gospel research. This is an important area which is still developing within rabbinic scholarship.

Neusner's work on the structure and progression of arguments in rabbinic texts has demonstrated the importance of redaction criticism, especially for dating the anonymous sources. He and others have shown that the redactors of Mishnah and other texts did not simply collect material and lay it down in a random order. They followed the natural progression of the arguments which, in many cases, spanned several generations. In doing so, they often preserved the chronological sequence of the material. This does not mean that anonymous material was simply collected in chronological order, or even that every reference to an anonymous source necessarily indicates that the anonymous source predated the person referring to it. But when the full rigors of redaction criticism are applied to a rabbinic text, it is often possible to date anonymous portions relative to attributed sources.

Neusner made an amazing claim in an early part of his work on Purities, namely that he could date virtually all anonymous sayings.

Unattributed sayings are not a great problem. In mKel they account for $1 / 10$ of the rulings, and most can be assigned to a time period. Of the 49 in mKel, 26 can be located to the Yavnean or Ushan period, and often to a particular circle of Rabbis within that period. They can be dated if they are 'closely tied to an attributed law, or are diametrically opposed to a tradition assigned to a specific person and so may with confidence be located in the same division as the contrary law. 33

This was perhaps over-enthusiastic, and he certainly appears more cautious in later works. However the principles are correct, and his later work went on to demonstrate in great detail that the editors of rabbinic works preserved much of the chronology of the debates, though this was not their primary concern. This chronological detail can often be deduced and used to date anonymous sources relative to the attributed sources which surround them.

The revised argument which I offered for Casey's discussion of Passover on the 13th of Nisan is an example of how redaction criticism can be used to augment other ways of looking at Mishnah. The discussion by R. Joshua and Ben Bathyra in mZeb. 1.3 is surprising, as Casey concluded. It is explicable in the context of a

33 Purities vol. 4, 244. 
debate about the foregoing ruling in $m Z e b .1 .1$. One cannot conclude that $m Z e b .1 .1$ dates before these rabbis simply because the editor placed it in front of their debate. But when one adds the fact that these Rabbis were unlikely to initiate this topic after $70 \mathrm{CE}$, and the fact that this is a relatively obscure ruling (so it is not an editorial summary), it becomes very likely that it predates their discussion. This is confirmed by the similar tradition at the end of mZeb. 1.3 which is attributed to the Sanhedrin of the Temple period.

Redaction criticism usually requires an examination of the larger context, and preferably the flow of the argument in the whole tractate. It is therefore understandable that scholars who occasionally dip into the Mishnah for a useful quotation will find this type of analysis difficult to perform. Redaction criticism is therefore a difficult but a very rewarding method of dating.

\section{Conclusions}

As seen in all three of these works, we live in a post-Neusner world. Even those who would prefer to ignore him, cannot ignore the climate change which his work has created. Neusner himself does not see much benefit in using rabbinic materials to help understand the Gospels. His contribution to a recent volume on interrelationships between Gospels and Mishnah/Tosephta suggested that one can read them both in parallel, but one should be wary of assuming that they interacted with each other. They both come from a similar milieu and they both work within a similar set of presuppositions, but the two sets of literature do not normally interact with each other. ${ }^{34}$ For example, they both have a similar attitude to Scripture:

...both compilations concur that the Hebrew Scriptures set forth authoritative teachings, but need not be emulated. Neither pretends to recapitulate the traits of Scripture. ${ }^{35}$

But even when they both exegete the same scripture, they are talking at cross purposes. One of Neusner's examples is the story of Jesus healing on a Sabbath, which Casey examined. Mark has 'Is it lawful

\footnotetext{
34 Neusner, 'Comparing Sources: Mishnah/Tosefta and Gospel', pp. 119-35 in Jewish Law from Moses to the Mishnah: The Hiram College Lectures on Religion for 1999 and Other Papers by J. Neusner (Scholars Press: Atlanta, 1999), pp. 130f.

35 Neusner, 'Comparing Sources', 119.
} 
on the Sabbath to do good or to do harm, to save life or to kill?' (Mk. 2:4). The rabbinic sources agree that one should save life, but one should not do any work of healing unless a life is at risk (tSabb. 15.11f.; 14.3). Strictly speaking, Jesus did not do any work (the arm was healed when it was stretched out). This leads Neusner to conclude that Jesus was not really interacting with the debate about work on a Sabbath - he was teaching that the important thing is not saving life or even doing work, but doing good. ${ }^{36}$

And anyway, Neusner would say, the Gospels are patently older than Mishnah/Tosephta, and one should use an older source to illustrate a later, not vice versa.

If we want to know the state of 'Jewish law' in the first century, we begin not with the Mishnah and its attributions of sayings to first century figures-these are beyond all tests of verification or falsification-but with the Gospels' stories themselves. These stand far closer to the events of which they speak than the Mishnah's counterpart laws. ${ }^{37}$

For this reason Neusner uses the Gospels to help date ancient rabbinic sources. Near the beginning of his Purities project he used Jesus' saying about inside and outside purity (Mt. 23:25f.; Lk. 11:39) to help date the rabbinic debate concerning the cleanliness of the inside of a vessel as distinct to the outside of a vessel. ${ }^{38}$

Strictly speaking, Neusner is correct. The final editing of the Gospels is certainly earlier than the final editing of any rabbinic sources, and the two literatures do interact very little. His interests are, however, very different from that of a New Testament scholar. He wishes to explore the meaning of the rabbinic material and is happy to use the Gospels for background material. The New Testament scholar wishes to use rabbinic material as background for Gospel studies. The New Testament scholar has the harder task, because dating is always the key issue. The late editing of the rabbinic material makes dating both an important issue and a difficult one.

The three works reviewed here demonstrate both the treasures and the problems waiting for the New Testament scholar in rabbinic literature. The Institute for Early Christianity in the Graeco-Roman World has begun a project using the types of dating method outlined above to encourage New Testament scholars to use rabbinic sources which are currently being neglected.

36 Neusner, 'Comparing Sources', 130f.

37 Neusner, 'Comparing Sources', $128 \mathrm{f}$.

38 Neusner, Purities vol. 3, 374-81. 